\title{
İki Yaş Altı Çocuklarda Sigara Mâruziyeti ve Tekrarlayan Bronşiyolit Atakları Arasındaki İlişkinin İncelenmesi
}

The Evaluation of Relationship Between Passive Smoking and Recurrent Episodes of Bronchiolitis in Children Under Two-years Old

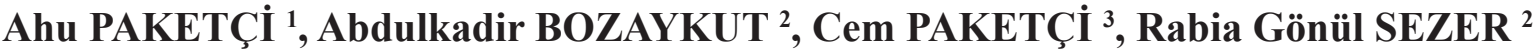 \\ 1. Tekirdağ Devlet Hastanesi, Çocuk Sağlığı ve Hastalıkları, Tekirdağ \\ 2. Zeynep Kamil Kadın ve Çocuk Hastalıkları Eğitim ve Araştırma Hastanesi, İstanbul \\ 3. Namık Kemal Üniversitesi Tıp Fakültesi, Çocuk Sağığı ve Hastalıkları, Tekirdağ
}

\section{$\ddot{O Z E T}$}

Giriş: Tekrarlayan hışıltı atakları özellikle sosyoekonomik düzeyi düşük olan ailelerde, kalabalık ortamda yaşayan, sigara dumanina mâruz kalan ve anne sütü alamayan bebeklerde daha sik olarak görülür.

Materyal ve Metod: Bu çalışma 2009-2011 tarihleri arasında, Çocuk Sağlığı ve Hastalıkları Kliniği'ne başvurup ilk atak bronşiyolit tanısı alan hastalarda prospektif olarak yapıldi.

Sonuçlar: Çalışmaya yaşları 1-24 ay olan toplam 500 infant dahil edildi. Evde sigara kullanımı hastalarin \%46,6'sinda $(n=233)$ mevcuttu. Tekrarlayan bronşiyolit atağl geçiren çocukların, evde sigara mâruziyet oranları istatistiksel olarak anlamlı derecede yüksek saptandı $(p<0,001)$.

Tartışma: Çalışmamızda, sigara maruziyeti tekrarlayan hışıltı atakları açısından risk faktörü olarak bulundu. Sigara dumanina mâruziyet azaltılarak tekrarlayan akut bronşiyolit ataklarının azaltılabileceğini düşünmekteyiz.

Anahtar Kelimeler: bronşiyolit, sigara, süt çocuğu

\section{SUMMARY}

Objective: Recurrent episodes of wheezing are more common in infants especially with low socioeconomic status who are exposed to smoking, who are not breastfed and lives in crowded families.

Material and Methods: This study was performed prospectively with infants diagnosed as first attack bronchiolitis from the outpatient clinics between 2009 to 2011.

Results: The study included 500 infants aged between 1-24 months. Cigarette smoking was present in $46.6 \%(n=233)$ of the families. There was a significant relationship between recurrent episodes of bronchiolitis and exposure to cigarette smoke $(p<0.001)$.

Conclusion: In this study, exposure to cigarette smoke was detected as a risk factor for recurrent episodes of bronchiolitis. The decrease of smoking in the population can prevent recurrence of bronchiolitis.

Keywords: bronchiolitis, smoking, infant

\footnotetext{
İletişim Bilgileri:

Sorumlu Yazar: Dr. Rabia Gönül Sezer

Yazışma Adresi: Opr. Dr. Burhanettin Üstünel Caddesi

No:10, Üsküdar, İstanbul, Turkiye

Tel: 02163910680

E-mail: rabiagonul@hotmail.com

Makalenin Geliş Tarihi: 08.07.2015

Makalenin Kabul Tarihi: 09.11.2015

DOI: http://dx.doi.org/10.16948/zktb.87611
} 


\section{GİRIS}

Çocuklarda, akut bronşiyolit sonrası tekrarlayan hışıltı atakları görülebilir. Çocukta ve ailede atopi ve alerji öyküsü, çocuğun solunum yollarının doğuştan dar olması, düşük sosyoekonomik düzey, kalabalık yaşam koşulları, anne sütü alamama, pasif sigara içiciliği tekrarlayan hıșıltı atakları gelișmesi için risk faktörleridir. Hamilelikte ve daha sonra yaşamın ilk dönemlerinde annenin sigara içiminin bebeğin alt solunum yolu infeksiyonu için önemli bir risk faktörü olduğu gösterilmiştir $(1,2)$. Hayvan çalışmaları gebelik sırasında içilen sigaranın elastin depolanmasını belirgin derecede azalttığ 1 ve fetal akciğerde elastik basıncı düşürdüğünü göstermiştir. Gebelik sırasında annenin sigara içimi, solunum yolları gelişimini etkilemekte ve solunum yollarının dar olmasina neden olmaktadır (3). Postnatal sigara mâruziyeti otit, bronşit, bronşiyolit, zatürre gibi alt solunum yolu enfeksiyon risklerini arttırmaktadır. Hastaneye yatırılan bronşiyolit vakalarında, evde sigara mâruziyeti olanlarda hastalığın daha ağır seyrettiği gösterilmiștir. Tüm alt solunum yolu enfeksiyonlarında, özellikle postnatal maternal sigara mâruziyetinde risk daha çok artmaktadır. Bebeklik döneminde akciğer fonksiyonları bozuk olan (bronșiyolit oluşmadan önce), pasif sigara dumanına maruz kalan, respiratuar sinsityal virüs infeksiyonu sırasında yüksek titrede virüs spesifik IgE yanıtı oluşturan bebeklerde tekrarlayan hışıltı daha sık görülmektedir.

$\mathrm{Bu}$ çalışmada, tekrarlayan bronșiyolit atakları ile postnatal sigara dumanına mâruziyet arasındaki ilişkiyi araştırdık.

\section{GEREÇ ve YÖNTEM}

$\mathrm{Bu}$ çalışma 2009-2011 tarihleri arasında, Çocuk Sağlığı ve Hastalıkları Kliniği'ne başvurup ilk atak bronşiyolit tanısı alan hastalarda prospektif olarak yapıldı. Çalışma öncesinde Zeynep Kamil Kadın ve Cocuk Hastalıkları Eğitim ve Araştırma Hastanesi Etik Kurulu'na çalışma hakkında ayrıntılı bilgi verilerek onay alındı. Çalışmaya gönüllü olarak katılmayı kabul eden ebeveynlere aydınlatilmıs hasta onam formu okutuldu ve imzalatıldı. Üst solunum yolu infeksiyonu semptomlarını (burun akınt1s1, öksürük, ateș, vb.) takiben birkaç gün içinde gelişen hışıltı, çekilme, taşipne, artmış solunum eforu ortaya çıan vakalar klinik olarak akut bronşiyolit olarak kabul edilip çalışmaya alındı. Hastaların öyküsü aileden aldıktan sonra ayrıntılı fizik muayene bulguları, hastanın yaşı, cinsiyeti ve sigara dumanına mâruziyeti sorguland1. Hastalar bir yıl süresiyle izleme alındı ve tekrarlayan ataklar kaydedildi.
Hastalar tek atak, 2 bronşiyolit atağ 1 ve $\geq 3$ atak olarak karşılaştırıldı. Üç ve üçten fazla atak geçiren hastalar tekrarlayan bronşiyolit olarak kabul edildi.

Çalışmada elde edilen verilerin değerlendirilmesinde istatistiksel analizler için SPSS (Statistical Package for Social Sciences, 15.0) kullanıldı. Sonuçlar anlamlılık $p<0,05$ kabul edilerek değerlendirildi.

\section{BULGULAR}

Çalışmaya yaşları 1-24 ay arası toplam 500 infant dahil edildi. \%39'u (n=195) k1z ve \%61'i $(n=305)$ erkek olan hastaların yas ortalaması $6,43 \pm 6,21$ (median=3,00) ay olarak saptand . Evde sigara kullanımı hastaların \%46,6'sında $(n=233)$ mevcuttu.

Hastalar, sigara mâruziyetine göre tek atak, 2 bronşiyolit atağı ve $\geq 3$ atak olarak karş1laştırıldı. Tekrarlayan bronşiyolit atağı geçiren çocukların, evde sigara mâruziyet oranları istatistiksel olarak anlamlı derecede yüksek saptan$\mathrm{d}_{1}(\mathrm{p}<0,001)$ (Tablo 1).

Tablo 1. Evde sigara mâruziyetinin, tek atak, 2 atak ve $\geq 3$ bronşiyolit atağı geçiren
çocuklardaki oranların değerlendirilmesi.
\begin{tabular}{|c|c|c|}
\hline & \multicolumn{2}{|c|}{ Sigara Mâruziyeti } \\
\cline { 2 - 3 } & Yok (n:267) & $\operatorname{Var}(\mathrm{n}: 233)$ \\
\hline Tek atak & $83(\% 31.1)$ & $27(\% 11.6)$ \\
\hline 2 Atak & $12(\% 4.5)$ & $15(\% 6.4)$ \\
\hline$\geq 3$ Atak & $172(\% 64.4)$ & $191(\% 82)$ \\
\hline
\end{tabular}

Hastaların atak sayısı, atak süresi ve ilk atak yaşı ortalamaları incelendiğinde, evde sigara kullanımının ilk atak yaşı üzerinde anlamlı etkisi bulunmazken, ortalama atak sayısı ve süresini anlamlı olarak uzattığı saptandı (Tablo 2).

Tablo 2. Evde sigara içilmesinin, geçirilen atak sayısı, atak süresi ve ilk atak yaşına etkisinin incelenmesi.

\begin{tabular}{|c|c|c|}
\hline & \multicolumn{2}{|c|}{ Evde Sigara Mâruziyeti } \\
\cline { 2 - 3 } & Yok & Var \\
\hline Atak sayısı & $4.06 \pm 2.49$ & $6.36 \pm 2.98$ \\
\hline Atak süresi (gün) & $4.16 \pm 1.5$ & $5.70 \pm 1.29$ \\
\hline İlk atak yaşı (ay) & $6.97 \pm 7.15$ & $5.82 \pm 4.85$ \\
\hline
\end{tabular}

\section{TARTIŞMA}

Çalışmamızda, sigara mâruziyeti tekrarlayan bronşiyolit atakları (3 ve üzeri) açısından anlamlı bir risk faktörü olarak bulundu.

İntrauterin sigara mâruziyetinin akciğerler üzerine etkisi net olmamakla birlikte, fetüste tip 2 pnömosit gelişiminin ve surfaktan yapımının azalması ve hava yolu gelișiminin bozulması, akciğer elastik komponent kaybı sonucunda fetal akciğer hareketlerinin deprese olmasina 
neden olabileceği gösterilmiştir (4). Çalışmamızda infantların postnatal sigara mâruziyetine bağlı anlamlı derecede tekrarlayan (3 ve üzeri) bronşiyolit atağı geçirdiği saptanmakla birlikte, prenatal sigara mâruziyeti sorgulanmadi. Postnatal sigara dumanı mâruziyeti olan infantların \%82'si 3 ve üzeri tekrarlayan bronşiyolit atağ 1 geçiriken, sigara dumanı mâruziyeti olmayan infantlarda 3 ve üzeri bronşiyolit atağı geçirme oranı \%64,4 saptandı. Çalışmamızda sigara dumanı mâruziyeti arttıkça, atak süresinin de anlamlı olarak arttığı, evde yaşayan kişi sayısı arttıkça infantların sigara dumanı mâruziyetinin daha fazla olduğu tespit edildi.

Lodrup ve ark. yaşamının ilk 2 yılında tekrarlayan ve persistan bronşiyal obstrüksiyon gelişen 77 infantla, gelişmeyen 88 infantın annelerinin gebelik boyunca sigara içmesini ve intrauterin sigara mâruziyetini karşılaştırarak yaptıkları vaka kontrol çalışmasında intrauterin sigara mâruziyeti olan hastaların yaşamının ilk 2 yılında daha çok tekrarlayan ve persistan bronşiyal obstrüksiyon geliştiği ve bu hastaların kord Ig E seviyelerinin daha yüksek olduğu saptanmıştır (4). Chulada ve ark.'nın 7766 infant ile yaptıkları kesitsel anket çalışmasında çalışmamıza benzer şekilde sigara mâruziyeti astım ve tekrarlayan hışıltı atakları açısından risk faktörü olarak bulunmuştur (5). 2011 y1lında 60 çalışmayı inceleyen bir meta-analizde, postnatal sigara mâruziyetinin intrauterin mâruziyetten daha fazla alt solunum yolu enfeksiyon riskini arttırdığ 1 ve riskin özellikle bronşiyolit için daha fazla olduğu gösterildi (6). Sadece baba evde sigara içtiğinde risk 1,22 kat, hem anne hem de baba içtiğinde ise risk 1,62 kat artmaktadır (6). Bronşiyolit tanısı ile hastaneye yatırılan 378 infant incelendiğinde, mekanik ventilasyon ve oksijen ihtiyacı olması ev içi sigara mâruziyeti ile ilişkili bulunmuş $(p<0,001)$ (7).

Arshad ve ark. 1456 infant üzerinde 10 yıllık takip ile yaptıkları ve 2005 yılında yayınladıkları bir çalışmada 0-4 yaş arası sigara dumanı mâruziyeti olmasının tekrarlayan hışıltı atakları için bir risk faktörü olduğunu bulmuşlardır (8). Lannerö ve ark. 1994-1996 yılları arasında 4089 infant üzerinde yaptıkları çalışmada gebelikte sigara içiminin tekrarlayan hışıltı ataklarını anlamlı derecede arttırdığını saptamışlardır (9). Postnatal dönemde annenin günde yirmiden fazla sigara içmesinin ani bebek ölümü ile ilişkili olduğu saptanmıştır (10). Rylander ve ark. ilk kez solunum yolu problemi (hışıltı) ile hastaneye yatırılmış olan 199 hastada yaptıkları vaka-kontrol çalışmasinda ebeveynlerden özellikle annenin sigara içmesi ile tekrarlayan bronşiyolit atakları arasında güçlü bir ilişki saptamışlar (11).

Gürkan ve ark. yaşları 2-18 ay arasında değişen infantlar üzerinde yaptıkları ve 2000 yılında yayınladıkları bir vaka kontrol çalışmasında pasif sigara içiciliğini özellikle respiratuar sinsityal virüs bronşiyoliti ve akut bronşiyolit açısından önemli bir risk faktörü olarak tespit etmişlerdir (11). Pasif sigara içiciliğin en önemli göstergesi idrar nikotin seviyesi akut bronşiyolit, post bronşiyolit ve kontrol grubunda karşılaştırıldığında akut bronşiyolit grubunda en yüksek saptanırken, kontrol grubunda en düşük saptanmıştır (11). Karaman ve ark.'nın yaşları 6-24 ay arası değişen tekrarlayan hışıltı tanısı olan 38 infant üzerinde yaptıkları vaka kontrol çalışmasında parental sigara mâruziyeti önemli bir risk faktörü olarak bulunmuştur (12).

Rullo ve ark. literatürdeki birçok yayının aksine çok düşük sosyoekonomik koşulları olan ve ailesinde astım risk faktörü bulunan 99 hastanın 30 aylık izlemi ile yaptıkları ve sonuçların1 2008 yılında yayınladıkları çalışmada sigara dumanına mâruziyetin tekrarlayan bronşiyolit atakları üzerine etkisi olmadığını bulmuşlardır (13).

Tekrarlayan hışıltı atakları için önleyici yöntemler kalabalık ortamlardan kaçınmak (örn. yuva) ve sigara dumanına mâruziyeti engellemektir. Sigara dumanına mâruziyet azaltılarak tekrarlayan akut bronşiyolit ataklarının azaltılabileceğini düşünmekteyiz.

\section{KAYNAKLAR}

1. Mc Connochie KM, Hall CB, Walsh EE, Raghman KJ. Variation in the severity of respiratory syncytial virus infections with subtype. J Pediatr 1999;117:52-62.

2. Wright AL, Holber C, Martinez FD, Taussig LM. Relationship of parenteral smoking to wheezing and nonwheezing respiratory tract illness. Group Health Medical Associates J Pediatr 1991;118: 207- 214.

3. Martinez FD. Definition of pediatric asthma nad associated risk factors. Pediatr Pulmonol 1997;15: 9- 12. 
4. Lodrup Carlsen KC, Carlsen KH, Nafstad P, Bakketeig L. Perinatal risk factors for recurrent wheeze in early life. Pediatr Allergy Immunol. 1999;10:89-95.

5. Chulada PC, Arbes SJ Jr, Dunson D, Zeldin DC. Breast-feeding and the prevalence of asthma and wheeze in children: analyses from the Third National Health and Nutrition Examination Survey, 1988-1994. J Allergy Clin Immunol. 2003;111:328-36.

6. Jones LL, Hashim A, McKeever T, Cook DG, Britton $J$, Leonardi-Bee J. Parental and household smoking and the increased risk of bronchitis, bronchiolitis and other lower respiratory infections in infancy: systematic review and meta-analysis. Respir Res. 2011;12:5.

7. Semple MG, Taylor-Robinson DC, Lane S, Smyth RL. Household tobacco smoke and admission weight predict severe bronchiolitis in infants independent of deprivation: prospective cohort study. PLoS One. 2011;6:e22425.

8. Arshad SH, Kurukulaaratchy RJ, Fenn M, Matthews S. Early life risk factors for current wheeze, asthma, and bronchial hyperresponsiveness at 10 years of age. Chest. 2005; 127:502-508.
9. Lannerö E, Wickman M, Pershagen G, Nordvall L. Maternal smoking during pregnancy increases the risk of recurrent wheezing during the first years of life (BAMSE) Respir Res. 2006;7:3.

10. Elliot J, Vullermin P, Robinson P. Maternal cigarette smoking is associated with increased inner airway wall thickness in children who die from sudden infant death syndrome. Am J Respir Crit Care Med. 1998;158:80206.

11. Gürkan F, Kiral A, Dăgli E, Karakoç F. The effect of passive smoking on the development of respiratory syncytial virus bronchiolitis. Eur J Epidemiol. 2000;16:4658.

12. Karaman O, Uguz A, Uzuner N. Risk factors in wheezing infants. Pediatr Int. 1999;41:147-50.

13. Rullo VE, Arruda LK, Cardoso MR, Valente V, Zampolo $A S$, Nóbrega F, Naspitz CK, Solé D. Respiratory infection, exposure to mouse allergen and breastfeeding: role in recurrent wheezing in early life. Int Arch Allergy Immunol. 2009; 150:172-8. 